\title{
An Everlasting Battle between Theoretical Knowledge and Practical Skills? The Joint Impact of Education and Professional Experience on Entrepreneurial Success
}

\author{
Agnieszka Kurczewska, Wirginia Doryń, Dorota Wawrzyniak
}

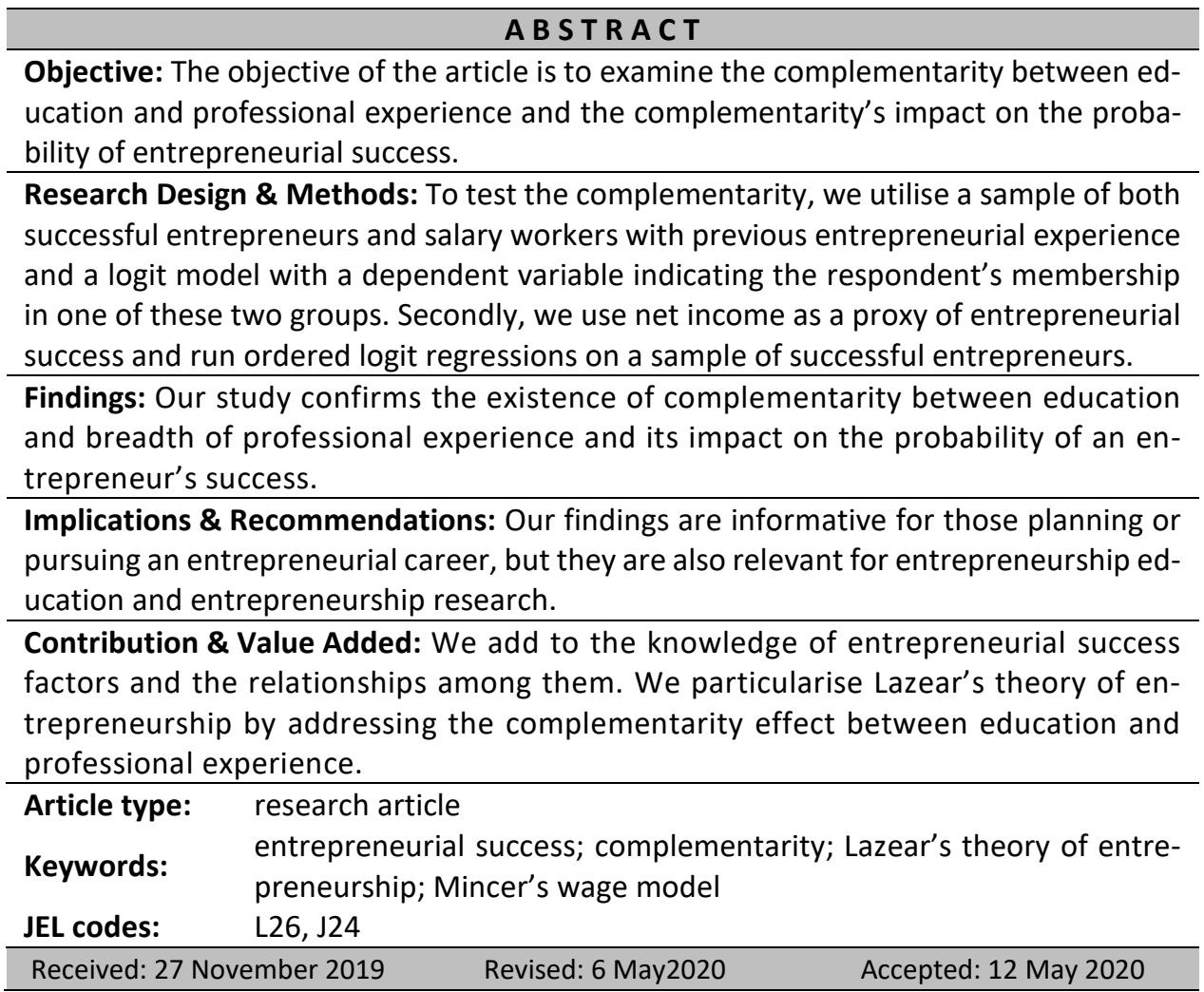

\section{Suggested citation:}

Kurczewska, A., Doryń, W., \& Wawrzyniak, D. (2020). An Everlasting Battle between Theoretical Knowledge and Practical Skills? The Joint Impact of Education and Professional Experience on Entrepreneurial Success. Entrepreneurial Business and Economics Review, 8(2), 219-237. https://doi.org/10.15678/EBER.2020.080212 


\section{INTRODUCTION}

The question on the essence of entrepreneurial success (Osborne, 1995) is not a new one. Nevertheless, the dilemma regarding what supports professional success in entrepreneurship still provokes numerous research discussions. Scholarship answers usually relate to human capital (Unger, Rauch, Frese, \& Rosenbusch, 2011). However, is the matter not more linked to theoretical knowledge delivered through formal education or practical skills developed by professional experience? As scholars, we often advocate for theory as the vehicle of knowledge that - by being abstracted - gains academic legitimacy. At the same time, we observe a dynamically changing world in which practice often precedes research, and in which students demand a more action-oriented approach and hands-on experience, which usually requires practice outside of schools. The question on the merits of theoretical preparation versus practical training for a professional career is particularly relevant if we position it in the domain of entrepreneurship, which by its nature is connected with learning by doing (Rasmussen \& Sørheim, 2006; Pittaway \& Cope, 2007) or experiential learning (Cope \& Watts, 2000; Rae \& Carswell, 2001; Cope, 2005; Corbett, 2005; Politis, 2005), just as it aspires to provide a scientifically proven explanation of the entrepreneurship phenomenon (Scott, 2001; Lamont, 2012). As a society, we aim to "produce" future successful entrepreneurs, but we challenge the problem of what dictates entrepreneurial success. In this everlasting battle between theoretical knowledge and practical skills, there are also voices arguing for a third way - a combination of the two (Iversen, Malchow-Møller, \& Sørensen, 2016) which we should address in the context of designing training programmes and curricula (Nieuwenhuizen \& Kroon, 2002).

We identify the research gap in the insufficiently recognized complementarity effect between education and professional experience, as empirical confirmation of this effect is scarce in the context of entrepreneurial success (Iversen et al., 2016). Moreover, many studies relate to the diverse sources of entrepreneurial intentions as preconditions for entrepreneurial behaviour (e.g. Krueger, Reilly, \& Carsrud, 2000; Sánchez, 2011) but do not focus on the complementarity effect between them and do not relate to more longstanding achievements beyond a business start-up success.

The aim of this article is to fill this research gap and test the complementarity between education and professional experience and the complementarity's impact on the probability of entrepreneurial success. We assume that neither only formal education nor only professional experience constitutes a sufficient condition to make a successful entrepreneur. Therefore, we hypothesise that in order to succeed, an entrepreneur requires a combination of the two, which is related to their complementarity. However, we not only aim to confirm the coexistence of both education and professional experience in building an entrepreneurial career, but we also suppose that there is a threshold that triggers the positive impact of education/professional experience on entrepreneurial success.

In this paper, we follow a similar line of reasoning to Iversen et al. (2016), studying the joint impact of education and professional experience on entrepreneurial success. In contrast to Iversen et al. (2016), we refer to business survival as the measure of entrepreneurial success. Our study mostly builds on Lazear's theory of entrepreneurship 
(2005) and develops this well-established theory even further. Lazear presumes that entrepreneurs must be competent in many diverse skills and have at least basic knowledge in numerous areas (Lazear, 2005); therefore, his theory connects entrepreneurial success with the breadth and diversification of education and experience. We extend Lazear's "jack-of-all-trades" hypothesis by additionally asking about the complementarity between education and professional experience. In our study, we also refer to Mincer's wage model (1974), which is an econometric specification for the relationship between wages and accumulated human capital: schooling and professional training. Hence, we relate to entrepreneurial success not only in terms of survival but also in terms of entrepreneurs' earnings.

In order to test the complementarity between education and professional experience and its impact on the probability of an entrepreneur's success, we use a sample of both 'successful' entrepreneurs and salary workers with previous entrepreneurial experience. The study was conducted in Poland. By successful entrepreneurs, we mean those who have run their company continuously, which we operationalise as a minimum of three consecutive years. This composition of the sample creates a unique opportunity to investigate what characteristics related to human capital have an effect on sustainably running a company among individuals who follow an entrepreneurial path. The sample in other studies that examine entrepreneurial success factors usually consists of entrepreneurs and non-entrepreneurs. We also used net income as a proxy of entrepreneurial success. In this case, we run ordered logit regressions and test our hypotheses on a sample of current entrepreneurs who have run their businesses for at least 36 months.

The paper contributes to the human capital stream of the literature on entrepreneurial success but also to the entrepreneurship education field. By investigating the joint impact of the diversification of experience and education, we add to the knowledge of entrepreneurial success factors and the relationships among them. Therefore, we particularise Lazear's theory of entrepreneurship by addressing the complementarity effect between education and professional experience. Our results are informative for the individuals who plan or follow an entrepreneurial career, but they are also applicable for the purposes of entrepreneurship education.

The paper is structured as follows. The next section describes the theoretical foundations of the paper. The discussion on Lazear's (2005) theory of entrepreneurship and Mincer's (1974) wage model leads to implications for our hypotheses. Next, we explain our methodological choices and sample composition. In the next section, we present the results of hypotheses testing, together with an interpretation of the results. The article ends with conclusion and thoughts on the relevance of theory and practice of entrepreneurship education.

\section{LITERATURE REVIEW}

From the perspective of human capital theory, both education and professional training are regarded as fundamental determinants of an individual's economic performance (Becker, 1993; Schultz, 1961). They increase human productivity through the development of knowledge and practical skills. Hence, the research endeavours focus on investigating the specifics of their impact on success in professional life. The classic model of this impact 
is illustrated by Mincer's wage model (Mincer, 1974), which is an econometric specification for the relationship between wages and accumulated human capital. References to human capital also gain in popularity in entrepreneurship research (Marvel, Davis, \& Sproul, 2016). One of the most seminal theories pertaining to human capital and entrepreneurial success is Lazear's theory of entrepreneurship (Orazem, Jolly, \& Yu, 2015; Kurczewska, Mackiewicz, Doryń, \& Wawrzyniak, 2020).

\section{Lazear's Theory of Entrepreneurship}

The theoretical framework of the paper is built around Lazear's theory of entrepreneurship, which is one of the most powerful explanations of individual selection into entrepreneurship (Hsieh, Parker, \& van Praag, 2017; Saiz-Alvarez, 2019). This theory, wellestablished in the field, assumes that the maximization of lifetime income is the fundamental motive motive for career choice. The theory states that to become an entrepreneur, an individual needs to be competent in various skills and have even an elementary knowledge, but in multiple areas (Lazear, 2005). Lazear calls this the "jack-of-all-trades" hypothesis. He links career choice both to education and professional experience. However, Lazear differentiates between two types of actors on the labour market: entrepreneurs and paid employees. For the first group, Lazear advocates a breadth of knowledge and skills, whereas for the second - depth. He assumes that to achieve success, entrepreneurs need general skills and knowledge in a variety of areas, while paid employees profit from being specialists in a narrow field required by the labour market (Sorgner \& Fritsch, 2018). In this sense, an entrepreneur's wider number of theoretical and practical skills - as a result of diverse backgrounds, a variety of formal and informal training, rich work experience, and different roles during their career and life - are replenished by the expertise of their employees who follow a single predefined path.

Lazear's theory was verified on 500 Stanford alumni who entered the labour market. His study proved that individuals who follow more diversified careers are more likely to become entrepreneurs. One of the explanations for this dependency provided by Lazear stems from the perception of career as the result of conscious investment: aspiring entrepreneurs are to test multiple and different roles in order to gain the knowledge and skills necessary to launch their ventures. Lazear's theory was challenged in many further studies - and most often confirmed. For example, the theory was positively validated by Åstebro and Thompson (2011), Aldén, Hammarstedt, and Neumann (2017), Backes-Gellner and Moog (2013), Hartog, van Praag, and van der Sluis (2010), Stuetzer, Obschonka, Davidsson, and Schmitt-Rodermund (2013), and Wagner $(2003,2006)$. However, there are also studies, like the one by Silva (2007), which did not uphold the "jack-of-all-trades" hypothesis. On top of that, there also appeared multiple attempts to broaden the theory (e.g. Tegtmeier \& Kurczewska, 2017; Strohmeyer, Tonoyan, \& Jennings, 2017).

One of the extensions of Lazear's theory is to include entrepreneurial self-efficacy as a factor that influences having an entrepreneurial career (Tegtmeier \& Kurczewska, 2017). Self-efficacy is commonly defined as "the belief in one's capabilities to organise and execute the courses of action required to manage prospective situations" (Bandura, 1995). In the entrepreneurship context, the concept relates to an individual's belief in and judgment of their own skills and abilities to achieve entrepreneurial goals (Baron, Mueller, \& Wolfe, 2016). Scholars proved self-efficacy to have a significant meaning in entrepreneurial processes (Zhao, Seibert, \& Hills, 2005). Therefore, besides the objectively verified diversity 
and breadth of education and professional experience, we also add in our study their perceptions as a factor that influences the probability of entrepreneurial success. In this sense, we also presume that the probability of a successful entrepreneurial career increases with the higher level of entrepreneurial self-efficacy.

However, the many follow-up studies - among which none questioned education and professional experience as key determinants of entrepreneurial success - never checked Lazear's theory for the mutual effects between the two. The question of whether education and professional experience complement each other, and in what circumstances, remains unanswered.

\section{Mincer's Wage Model}

The basic assumption around which human capital theories are built is the existence of some skills that individuals on the labour market have as a form of capital and in which they invest. Most human capital theories relate to Mincer and his concept of investment in human capital. Mincer's wage model (1974) is a widely used equation to estimate the earnings effects of two types of human investments: schooling and work experience. The model explains wage income as a function of formal education, typically measured as the sum of years and experience modelled as a quadratic function of the years of potential experience. The model assumes the existence of both education and experience as substitutes in generating skills, and thus ignoring their possible complementary effect. Following Mincer's idea that education and professional experience are fundamental human capital factors related to a successful professional career expressed by earnings, we claim that the two may happen at the same time - and that they complement each other.

We limit our considerations to entrepreneurship and entrepreneurial success, which reinforces our claim for the potential complementarity between education and professional experience, because in light of Lazear's theory the broader and more diversified the skills - both theoretical and practical - the higher the probability of success as an entrepreneur. Accordingly, the issue of the complementarity of different skills becomes critical. Therefore, although in Mincer's equation log earnings are additively separable in schooling and experience, we follow the line of thought of Iversen et al. (2016) by arguing in our study that education and professional experience result in skills that are complements to entrepreneurial success. However, in addition to Iversen et al. (2016), we also emphasise the breadth of professional experience. Moreover, again with Lazear's theory in mind, we speculate that the complementarity effect between the two might not always work, as in the case of extremely low levels of education/professional experience.

Critically drawing both from Lazear's theory of entrepreneurship and Mincer's wage model, the above discussion leads us to two hypotheses:

H1: There is a complementarity between education and professional experience in determining entrepreneurial success.

H2: As professional experience/education increases, there is a threshold that triggers the positive impact of education/professional experience on entrepreneurial success. 


\section{MATERIAL AND METHODS}

To test the complementary effect of education and professional experience, we estimate the following base model:

$$
\text { suc }=\alpha_{0}+\alpha_{1} e d u+\alpha_{2} \exp +\alpha_{3} e d u \times \exp +\alpha_{4} \text { age }+\alpha_{5} \operatorname{sex}+\alpha_{6} k i d s+\varepsilon
$$

Suc stands for entrepreneurial success operationalised with two measures. Firstly, we proxied it as a survival of the business for at least three years. The three-year survival rate of Polish enterprises reaches above $40 \%$, and the four-year rate equals approximately $35 \%$ (CSO, 2014), which indicates that this period is vital for the further existence of an enterprise. Therefore, the first dependent variable is a dummy equal to 1 for entrepreneurs who managed to sustain their businesses for at least 36 months and 0 for wage workers who were previously entrepreneurs.

Our second success proxy is the level of net entrepreneurial income expressed by an ordinal variable with six categories (see Table 1 for details). Edu and exp mean general expressions that reflect education and professional experience, respectively. Education is measured by the highest completed level of education (ledu) and - alternatively - by the number of studies undertaken but not necessarily completed (stud). The breadth of experience is expressed in two ways, namely by the number of areas (exp) and industries (bexp) in which the individual possesses professional experience. We also introduce a set of control variables that express the individuals' age (age), sex (sex), and the number of children (kids). We then augment the baseline specification of the model with two additional explanatory variables. The first one (necess) refers to the literature that analyses the necessity of entrepreneurship, as it indicates whether initiating a business activity was determined by the failure to get another job or for other reasons. The second variable (askills) reflects the selfassessment of skills in different business-related areas. We expect that being a necessitydriven entrepreneur correlates negatively with entrepreneurial success, while the higher assessment of one's entrepreneurial skills translates into both higher earnings and the probability of sustaining a business throughout the given threshold period.

The data was obtained through telephone interviews conducted by an established Polish research institute with the CATI method. The questionnaire was developed by the research team and revised after a pilot study; the pilot study confirmed the logic of surveys and appropriateness of questions, which effected in minor changes to the wording of some questions to ensure clarity. The data collection (interviews proceeded by screening calls) took place in Poland in December 2017 and January 2018. The sample was randomly selected from the pool of individuals and companies with a Polish telephone number by using random digit dialling; they were then interviewed. In the process of initial filtering, surveys were administered only to adults who fell into one of the following categories: a self-employed individual or a non-self-employed individual who was previously an entrepreneur.

We test the complementarity between education and professional experience using two different schemas. Firstly, we utilise the full sample $(\mathrm{N}=1470)$ of both 'successful' entrepreneurs $(\mathrm{N}=693)$ and salaried workers with previous entrepreneurial experience $(\mathrm{N}=777)$ and a logit model with a dependent variable that indicates the respondent's membership in one of these two groups. Secondly, we use net income as a proxy of entrepreneurial success. In this case, we run ordered logit regressions and test our hypotheses on the sample of current entrepreneurs who have run their businesses for at least 36 months $(N=693)$. 
Table 1. List of variables and operationalization

\begin{tabular}{|c|c|}
\hline Variable & Operationalization \\
\hline $\begin{array}{l}\text { Dependent } \\
\text { variable } \\
(\text { suc })\end{array}$ & $\begin{array}{l}\text { Dummy variable: } \\
1 \text { - entrepreneurs who sustained their businesses for at least } 36 \text { months } \\
0 \text { - wage workers who were previously entrepreneurs } \\
\text { Alternative measure - level of net income: } \\
1 \text { - up to } 2000 \text { PLN } \\
2 \text { - } 2001 \text { - } 4000 \text { PLN } \\
3-4001 \text { - } 6000 \text { PLN } \\
4-6001 \text { - } 8000 \text { PLN } \\
5-8001 \text { - } 10000 \text { PLN } \\
6 \text { - more than } 10000 \text { PLN }\end{array}$ \\
\hline $\begin{array}{l}\text { Number of different } \\
\text { fields of studies (stud) }\end{array}$ & $\begin{array}{l}\text { Sum of declared different fields of studies undertaken (but not necessarily } \\
\text { completed) }\end{array}$ \\
\hline $\begin{array}{l}\text { Highest earned } \\
\text { level of } \\
\text { education } \\
(\text { ledu) }\end{array}$ & $\begin{array}{l}\text { The highest completed level of education: } \\
0 \text { - primary education or no education } \\
1 \text { - basic vocational education } \\
2 \text { - secondary vocational /secondary general education } \\
3 \text { - post-secondary education } \\
4 \text { - tertiary education } \\
\end{array}$ \\
\hline $\begin{array}{l}\text { Professional } \\
\text { experience } \\
\text { (exp) }\end{array}$ & $\begin{array}{l}\text { The number of different areas in which the respondents declared professional } \\
\text { experience, including the areas of production and services, shopping and main- } \\
\text { taining contacts with suppliers, logistics, marketing, sales, customer relations, } \\
\text { financial management and accounting, human resource management, others } \\
\text { (to be indicated by the respondent). }\end{array}$ \\
\hline $\begin{array}{l}\text { Professional } \\
\text { experience } \\
\text { (bexp) }\end{array}$ & $\begin{array}{l}\text { The number of different industries in which the respondents declared profes- } \\
\text { sional experience, including the following industries: industry/production, con- } \\
\text { struction, trade, agriculture, transportation, other branches of production, hos- } \\
\text { pitality and catering, science and technology development, education and up- } \\
\text { bringing, culture and art, health protection and social welfare, physical culture, } \\
\text { tourism and leisure, other branches of services, state administration and jus- } \\
\text { tice, finance and insurance, others (to be indicated by the respondent). }\end{array}$ \\
\hline $\begin{array}{l}\text { Reason for } \\
\text { launching } \\
\text { a business } \\
\text { (necess) }\end{array}$ & $\begin{array}{l}\text { Dummy variable: } \\
1 \text { - respondents who declared initiating a business activity because they "could } \\
\text { not find another job" (necessity entrepreneurs) } \\
0 \text { - respondents who declared other reasons of starting a business (i.e., desire } \\
\text { for self-realisation, an idea for a product or service unavailable on the market, } \\
\text { unwillingness to work as a full-time employee, chance to combine family re- } \\
\text { sponsibilities with earning, a promising partner, taking over a family business). }\end{array}$ \\
\hline $\begin{array}{l}\text { Self-efficacy } \\
\text { (askills) }\end{array}$ & $\begin{array}{l}\text { The level of entrepreneurial self-efficacy calculated as the sum of the respond- } \\
\text { ents' self-assessment of skills in the areas of financial management and ac- } \\
\text { counting, sales, marketing and advertising, human resource management, cus- } \\
\text { tomer relations, logistics and shopping, product design, and IT systems on } \\
\text { a 5-point Likert scale (1=very poor, } 5=\text { =very good). }\end{array}$ \\
\hline Age (age) & Years \\
\hline $\begin{array}{l}\text { Sex } \\
(\operatorname{sex})\end{array}$ & $\begin{array}{l}\text { Dummy variable: } \\
1 \text { - male } \\
0 \text {-female } \\
\end{array}$ \\
\hline $\begin{array}{l}\text { Number of child } \\
\text { (kids) }\end{array}$ & children \\
\hline
\end{tabular}

Source: own compilation. 
The sample descriptive statistics are given in Table 2.

Table 2. Descriptive statistics

\begin{tabular}{|c|c|c|c|c|}
\hline \\
\hline Variable & Mean & Std. Dev. & Min & Max \\
\hline \multicolumn{5}{|c|}{ Entrepreneurs $(\mathrm{N}=693)$} \\
\hline Net income (dependent variable) & 3.81 & 1.66 & 1 & 6 \\
\hline Number of different fields of studies (stud) & 0.82 & 0.93 & 0 & 4 \\
\hline Highest earned level of education (ledu) & 3.02 & 1.17 & 0 & 4 \\
\hline Professional experience (exp) & 1.96 & 2.12 & 0 & 9 \\
\hline Professional experience (bexp) & 1.34 & 1.37 & 0 & 9 \\
\hline Reason of launching a business (necess) & 0.09 & 0.29 & 0 & 1 \\
\hline Self-efficacy (askills) & 28.07 & 4.58 & 12 & 40 \\
\hline Age (age) & 46.95 & 10.67 & 24 & 68 \\
\hline Sex (sex) & 0.68 & 0.47 & 0 & 1 \\
\hline Number of children (kids) & 1.56 & 1.10 & 0 & 6 \\
\hline \multicolumn{5}{|c|}{ Ex-entrepreneurs - wage workers $(\mathrm{N}=777)$} \\
\hline Number of different fields of studies (stud) & 0.57 & 0.71 & 0 & 3 \\
\hline Highest earned level of education (ledu) & 2.78 & 1.24 & 0 & 4 \\
\hline Professional experience (exp) & 1.14 & 1.66 & 0 & 8 \\
\hline Professional experience (bexp) & 1.21 & 1.36 & 0 & 7 \\
\hline Reason of launching a business (necess) & 0.24 & 0.43 & 0 & 1 \\
\hline Self-efficacy (askills) & 25.38 & 4.98 & 8 & 40 \\
\hline Age (age) & 45.85 & 11.06 & 20 & 67 \\
\hline Sex (sex) & 0.44 & 0.50 & 0 & 1 \\
\hline Number of children (kids) & 1.49 & 1.11 & 0 & 7 \\
\hline
\end{tabular}

Source: own elaboration in Stata 15.

\section{RESULTS AND DISCUSSION}

The estimation results for the model that employs entrepreneurial survival for at least 36 months as a measure of success are given in Table 3 . The first four columns report the results for the augmented specification, while the next four columns are for the baseline specification. In all equations, the coefficients on the interaction term (studxexp, studxbexp, leduxexp, and leduxbexp) are positive and statistically significant at the $1 \%$ level, which indicates the existence of complementarity between education and professional experience. These results give strong support to our first hypothesis $(\mathrm{H} 1)$ which postulates that - to succeed - an entrepreneur needs a combination of both practical and theoretical skills. Among the control variables representing age, sex, and the number of children, only sex determines entrepreneurial success in a statistically significant manner. The coefficient on the sex dummy suggests that businesses run by men are more likely to survive.

The impact of additionally incorporated variables that reflect the reason for starting a business and self-efficacy is statistically significant across all models. It indicates that the probability of an enterprise surviving increases with higher self-efficacy, while necessity entrepreneurs experience a decrease in the probability that their company will survive. 
Table 3. Logit estimates for entrepreneurial success (entrepreneurial survival for at least 36 months)

\begin{tabular}{|c|c|c|c|c|c|c|c|c|}
\hline Variable & (1) & (2) & (3) & (4) & (5) & (6) & (7) & (8) \\
\hline stud & $-0.1809 *$ & -0.1905 & & & $-0.1960 *$ & $-0.2178 *$ & & \\
\hline exp & -0.0400 & & $-0.1805^{*}$ & & -0.0264 & & $-0.2220 * *$ & \\
\hline studxexp & $0.2806^{* * *}$ & & & & $0.3113^{* * *}$ & & & \\
\hline age & 0.0076 & 0.0063 & 0.0075 & 0.0066 & 0.0052 & 0.0034 & 0.0050 & 0.0034 \\
\hline $\operatorname{sex}$ & $0.9389^{* * *}$ & $0.9952 * * *$ & $0.9156 * * *$ & $0.9578 * * *$ & $0.9335^{* * *}$ & $0.9982 * * *$ & $0.9167 * * *$ & $0.9658^{* * *}$ \\
\hline kids & 0.0239 & 0.0264 & 0.0097 & 0.0088 & 0.0382 & 0.0397 & 0.0230 & 0.0207 \\
\hline necess & $-1.1052 * * *$ & $-1.1149 * * *$ & $-1.1218 * * *$ & $-1.1075 * * *$ & & & & \\
\hline askills & $0.0958 * * *$ & $0.1018 * * *$ & $0.0969 * * *$ & $0.1032 * * *$ & & & & \\
\hline bexp & & $-0.2883 * * *$ & & $-0.7105 * * *$ & & $-0.3023 * * *$ & & $-0.8269 * * *$ \\
\hline stud $\times$ bexp & & $0.4089 * * *$ & & & & $0.4657 * * *$ & & \\
\hline ledu & & & -0.0985 & $-0.1716^{* *}$ & & & $-0.1132 *$ & $-0.2016 * * *$ \\
\hline leduxexp & & & $0.1162 * * *$ & & & & $0.1412 * * *$ & \\
\hline leduxbexp & & & & $0.2386 * * *$ & & & & $0.2853^{* * *}$ \\
\hline Constant & $-3.5949 * * *$ & $-3.4810 * * *$ & $-3.4048 * * *$ & $-3.1035 * * *$ & $-1.1621 * * *$ & $-0.8344 * * *$ & $-0.9079 * * *$ & -0.3333 \\
\hline $\mathrm{N}$ & 1470 & 1470 & 1470 & 1470 & 1470 & 1470 & 1470 & 1470 \\
\hline Pseudo- $^{2}$ & 0.159 & 0.151 & 0.144 & 0.138 & 0.104 & 0.0911 & 0.0864 & 0.0768 \\
\hline$\chi^{2}$ & 196.1 & 202.8 & 210.0 & 202.6 & 121.3 & 123.1 & 134.1 & 111.4 \\
\hline
\end{tabular}

Source: own elaboration in Stata 15.

To validate hypothesis 2 , the analysis needs to be accompanied by the corresponding figures that present the marginal effects of education and professional experience on entrepreneurial success. In order to conserve space, we demonstrate figures only for the augmented model, which is our preferred specification. The analysed effect is considered statistically significant when its two-tailed $95 \%$ confidence interval lies above or below the zero line. Figure 1 depicts the average marginal effect of the number of fields of studies undertaken (stud) as professional experience changes - measured with the number of different areas (exp) - whereas Figure 2 shows the average marginal effect of professional experience dependent on the number of fields of studies undertaken. According to Figure 1, the probability of success increases with the number of fields of studies undertaken, when the number of areas of experience is large enough (and here it amounts to at least two). The effect is statistically insignificant in the case of a lack of experience or experience only in a single area. Figure 2 indicates that the probability of success increases with professional experience when undertaking at least one field of studies. The figures provide evidence for the presence of complementarity between education and professional experience $(\mathrm{H} 1)$. They also support our second hypothesis $(\mathrm{H} 2)$, that there is a threshold that triggers the positive impact of education/professional experience on entrepreneurial success, as the mutual effect between regressors became statistically significant and positive, starting from a threshold value.

Figures 3 and 4 depict the average marginal effect for the variables that measure education with the highest level of education earned, and professional experience with the sum of industries. The general finding regarding the complementarity of education and professional experience remains unchanged ( $\mathrm{H} 1$ holds). Figure 3 indicates that the statistically significant positive marginal effect of the level of education is triggered by professional experience gained in at least two fields. The effect was negative and statistically significant in the 


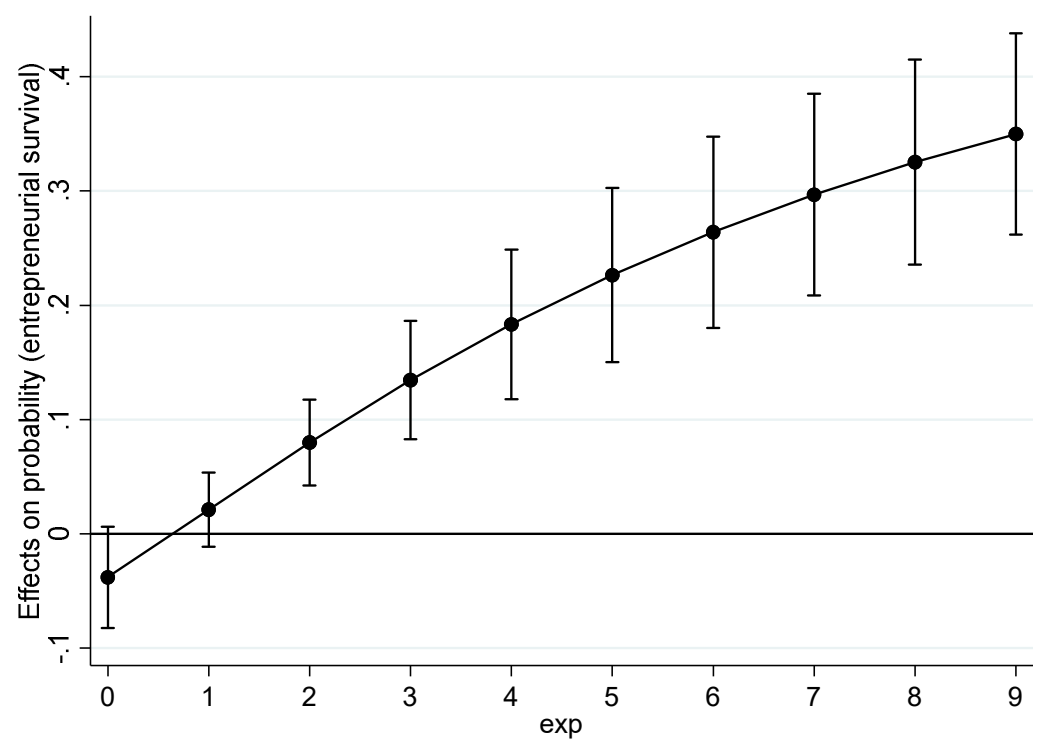

Figure 1. Average marginal effects of stud as exp changes, based on the estimation for entrepreneurial survival ( $95 \%$ confidence intervals)

Source: own elaboration in Stata 15.

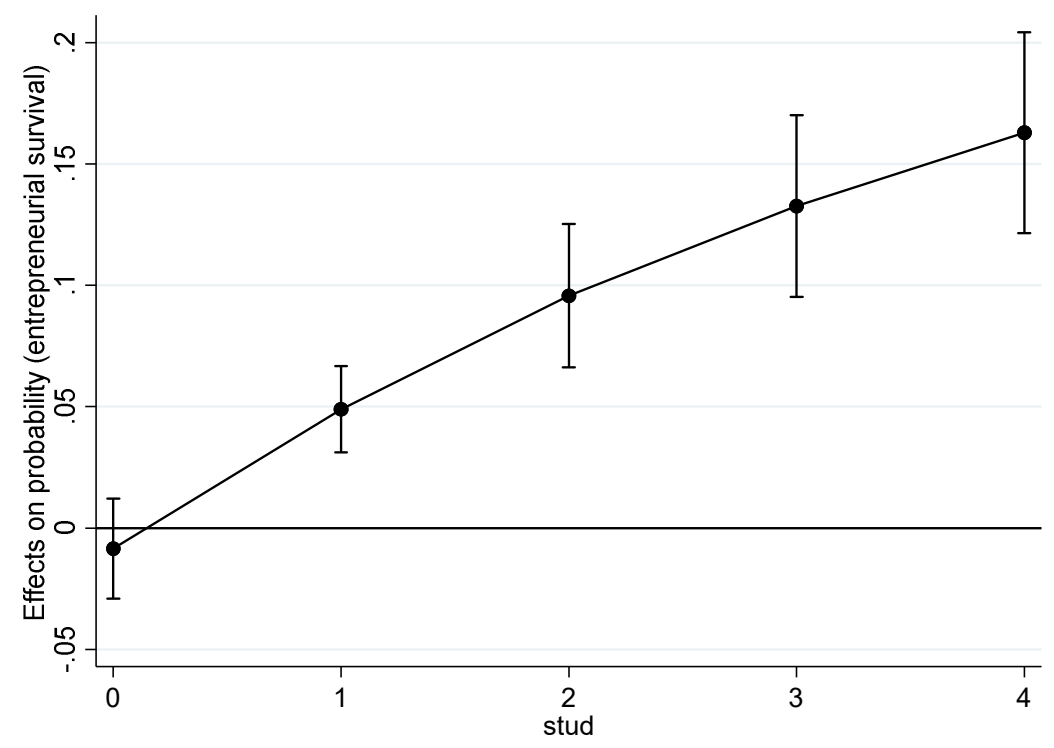

Figure 2. Average marginal effects of exp as stud changes, based on the estimation for entrepreneurial survival ( $95 \%$ confidence intervals)

Source: own elaboration in Stata 15. 
case of the lack of any experience, while it is insignificant for experience in only one field. According to Figure 4, the marginal effect of the increase in professional experience on the probability of survival is positive and statistically significant for the level of tertiary education, while it is statistically insignificant in the case of post-secondary education and is statistically significant and negative for lower levels of education. These results agree with our second hypothesis $(\mathrm{H} 2)$ on the threshold level triggering the positive impact of the combination of education and professional experience on entrepreneurial survival.

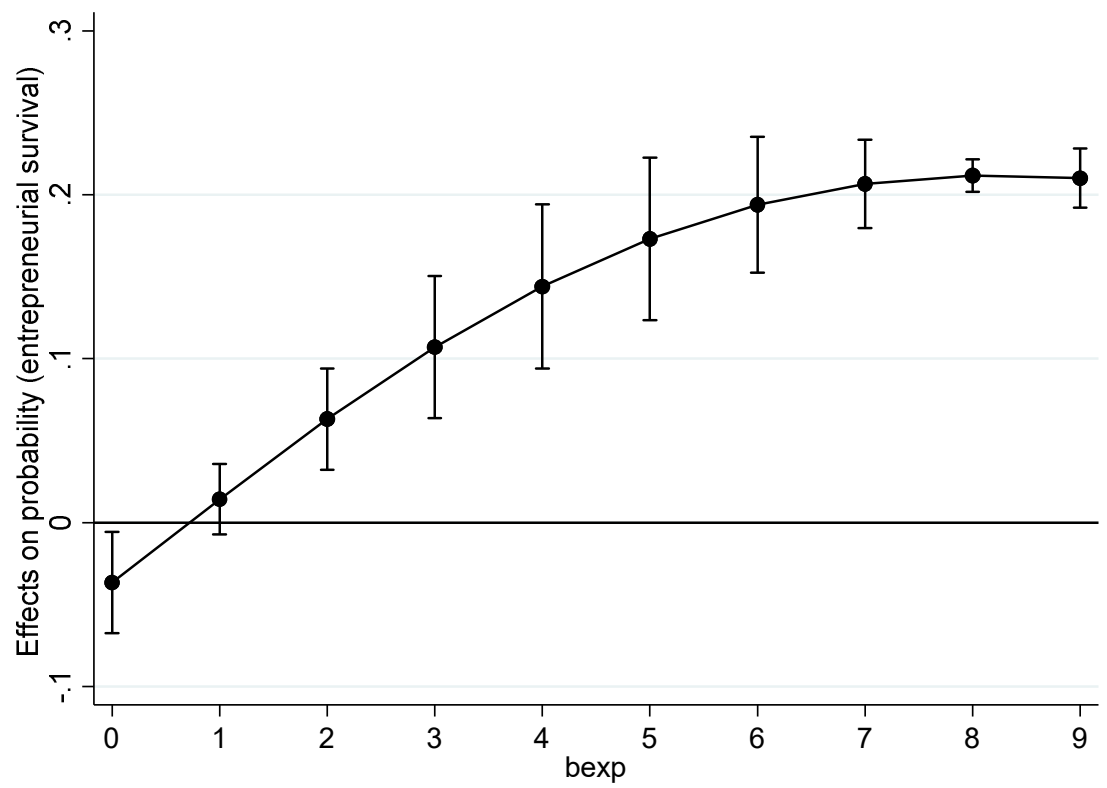

Figure 3. Average marginal effects of ledu as bexp changes, based on the estimation for entrepreneurial survival ( $95 \%$ confidence intervals) Source: own elaboration in Stata 15.

The ordered logit estimations for the model with net income as the dependent variable are presented in Table 4. The impact of the interaction term is statistically significant for both models (augmented and base) only in the case of studxexp, namely when the number of fields of studies undertaken is used as a proxy for education, along with professional experience measured by the number of areas. For the variables ledu and exp, the analysed effect is statistically significant at the $10 \%$ level in the extended model and $5 \%$ in the base one. In other cases, the impact of the interaction term is statistically insignificant. Hence, the presented results lend only partial support to our first hypothesis $(\mathrm{H} 1)$, i.e. the existence of complementarity between education and professional experience on entrepreneurial income. We suspect that these ambiguous results might be related to the deficiency in income variable used as a proxy for entrepreneurial success. We consider business survival/failure as a superior proxy of entrepreneurial success as it is an objective and ultimate measure of business performance. Discussion regarding other variables are analogous to previous models. 


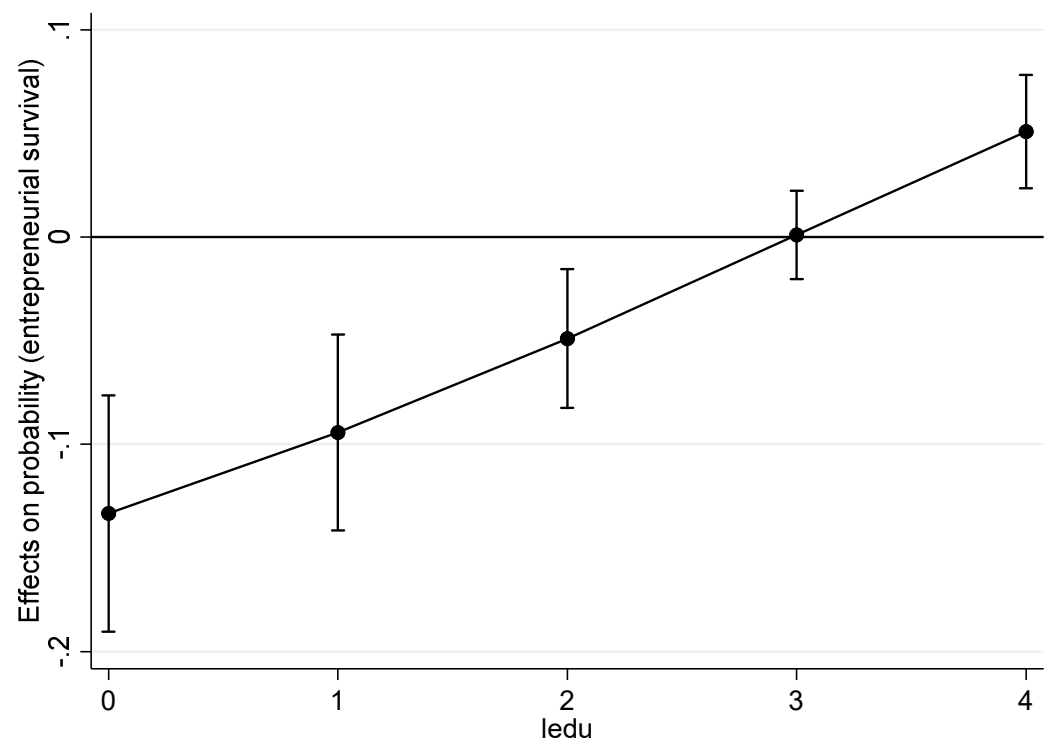

Figure 4. Average marginal effects of bexp as ledu changes, based on the estimation for entrepreneurial survival ( $95 \%$ confidence intervals)

Source: own elaboration in Stata 15.

Table 4. Ordered logit estimates for entrepreneurial success (income)

\begin{tabular}{|c|c|c|c|c|c|c|c|c|}
\hline Variable & (1) & (2) & (3) & (4) & (5) & (6) & (7) & (8) \\
\hline stud & 0.0173 & 0.1914 & & & 0.0016 & 0.1895 & & \\
\hline exp & -0.0129 & & -0.0871 & & -0.0220 & & -0.1113 & \\
\hline studxexp & $0.0818^{* *}$ & & & & $0.0931 * * *$ & & & \\
\hline age & -0.0008 & -0.0010 & -0.0023 & -0.0026 & $\begin{array}{l}-0.0022 \\
\end{array}$ & -0.0025 & -0.0039 & -0.0041 \\
\hline sex & $0.3284 * *$ & $0.3716 * *$ & $0.3059 * *$ & $0.3462 * *$ & $0.2798 *$ & $0.3299 * *$ & $0.2576^{*}$ & $0.3057^{* *}$ \\
\hline kids & 0.0864 & 0.0918 & 0.0743 & 0.0766 & 0.0850 & 0.0913 & 0.0724 & 0.0778 \\
\hline necess & $-1.0873 * * *$ & $-1.0809 * * *$ & $-1.1039 * * *$ & $-1.0796 * * *$ & & & & \\
\hline askills & $0.0391 * *$ & $0.0434 * * *$ & $0.0392 * *$ & $0.0439 * * *$ & & & & \\
\hline bexp & & -0.0706 & & -0.0732 & & -0.0848 & & -0.1428 \\
\hline studxbexp & & 0.0469 & & & & 0.0566 & & \\
\hline ledu & & & -0.0309 & 0.0791 & & & -0.0345 & 0.0673 \\
\hline leduxexp & & & $0.0528 *$ & & & & $0.0605^{* *}$ & \\
\hline leduxbexp & & & & 0.0276 & & & & 0.0480 \\
\hline$N$ & 693 & 693 & 693 & 693 & 693 & 693 & 693 & 693 \\
\hline Pseudo- $\mathrm{R}^{2}$ & 0.0243 & 0.0214 & 0.0214 & 0.0181 & 0.0119 & 0.00847 & 0.00868 & 0.00513 \\
\hline$\chi^{2}$ & 61.10 & 52.77 & 51.57 & 43.00 & 30.64 & 21.15 & 21.68 & 11.25 \\
\hline
\end{tabular}

Source: own elaboration in Stata 15.

To test our second hypothesis $(\mathrm{H} 2)$, we present Figures 5 and 6 , which illustrate the marginal effects that professional experience (education) has on entrepreneurial income as the level of education (professional experience) changes. According to Figure 5, the probability of earning a very high income (category 6-above 10000 PLN) increases with the number of 
areas of professional experience, which is conditional on having undertaken at least one field of studies. In turn, the probability of earning an income in the three lowest categories (1-3 - below 6000 PLN) falls. For income categories 4 and 5 (6 $000-8000$ PLN and 8000 10000 PLN, respectively), the relationship is statistically insignificant and not presented on the graph for the sake of clarity. For non-students (stud equal to 0 ), all the effects remain statistically insignificant. Figure 6 indicates that the probability of earning the highest income increases with the number of fields of studies undertaken if the person has experience of working in at least two different areas. At the same time, the probability of earning an income in three lowest categories decreases for entrepreneurs with experience in two or more areas, while it is insignificant for those with more modest experience. The average marginal effects in the case of the leduxbexp interaction are statistically insignificant for all income categories and, thus, we do not present them. Our empirical findings agree with our hypotheses, albeit the assumed effects appear only in some specifications. In sum, the estimation results of the income model only partially support our claims.

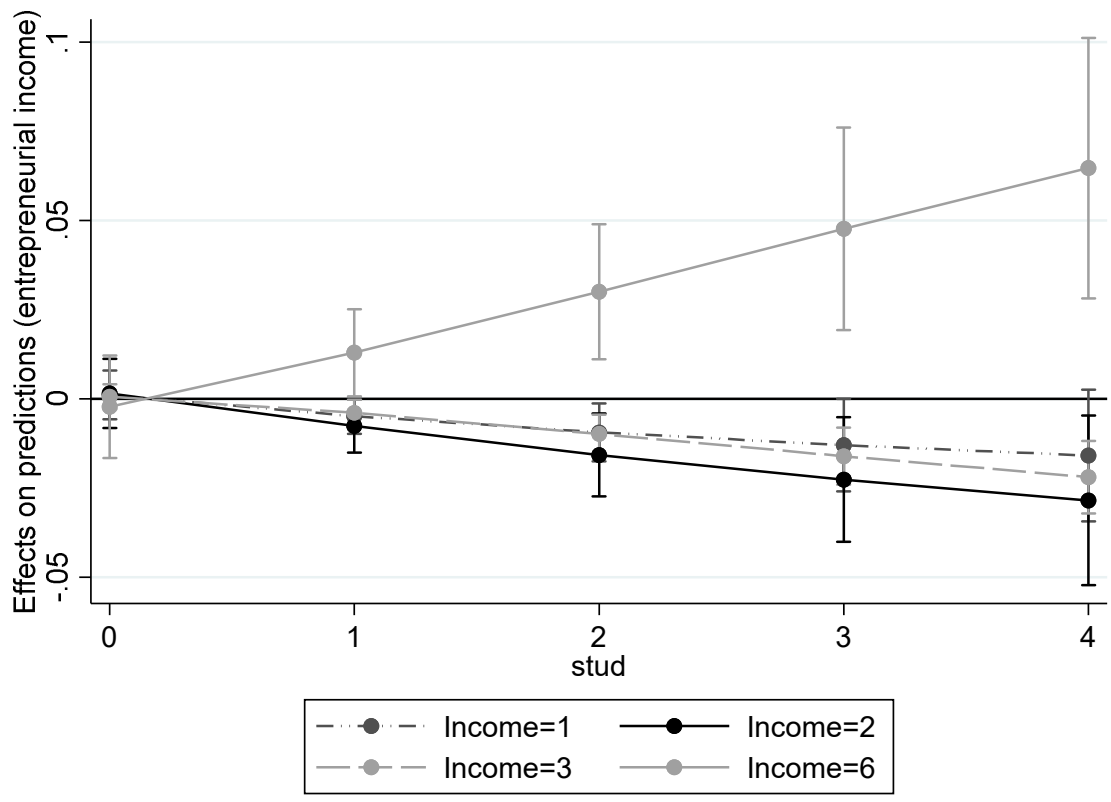

Figure 5. Average marginal effects of exp as stud changes, based on the estimation for entrepreneurial income ( $95 \%$ confidence intervals) Source: own elaboration in Stata 15.

To summarise, our general finding regarding the complementarity of formal education (explicit knowledge) and professional experience (tacit knowledge) supports the results of Iversen et al. (2016), who empirically confirmed the significance of interaction effect between these two types of human capital in determining entrepreneurial success. However, our study not only provides an additional robustness check test, using a new dataset, but also provides new insight from the long-term success perspective, namely the survival of established enterprises. 


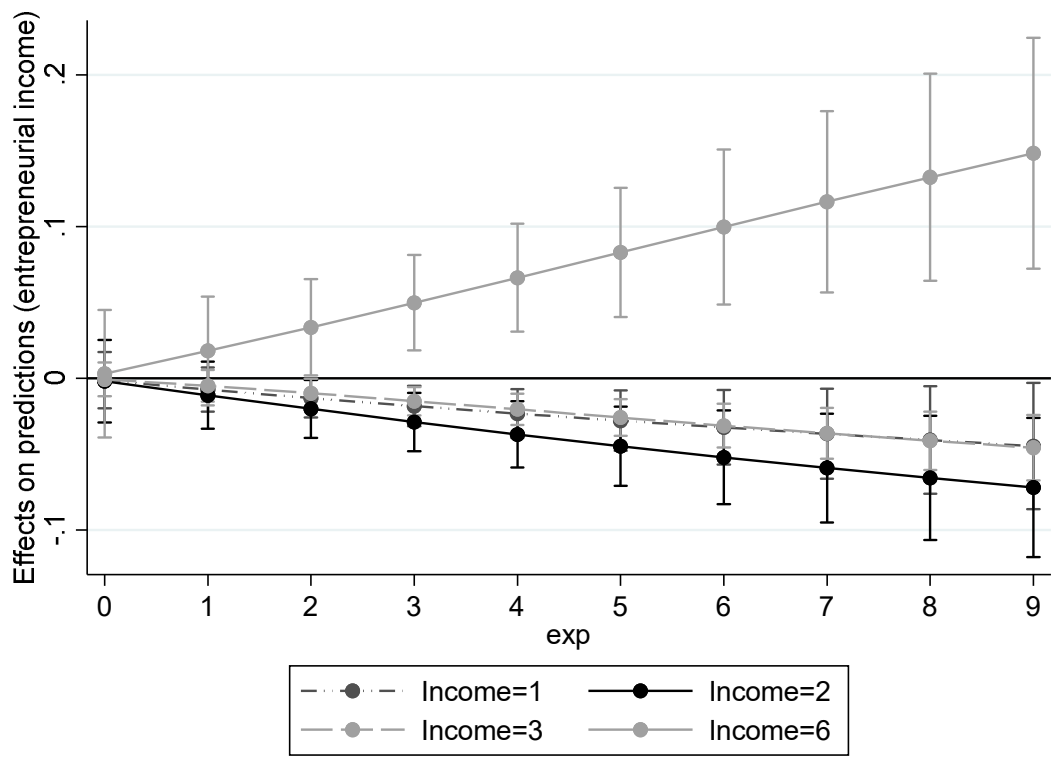

Figure 6. Average marginal effects of stud as exp changes, based on the estimation for entrepreneurial income ( $95 \%$ confidence intervals)

Source: own elaboration in Stata 15.

We also discovered some unintended results in our study that might require further comments. Firstly, in light of our research, businesses run by men are more likely to survive. This result may be interpreted in a way that female entrepreneurs are more constrained in terms of the amount and quality of human capital that they gained while employed (Boden \& Nucci, 2000; Fairlie \& Robb, 2009) or have less start-up capital and less prior work experience in a family business (Fairlie \& Robb, 2009). Similar findings were obtained in a study by Watson (2003). Secondly, our study reveals the role of self-efficacy in determining entrepreneurial processes. This finding agrees with other studies, e.g. McGee, Peterson, Mueller, and Sequeira (2009) or Zhao et al. (2005), who confirm the positive relationship between entrepreneurial intentions (as the prediction of entrepreneurial behaviour) and entrepreneurial self-efficacy, but also of Pollack, Burnette, and Hoyt (2012), who highlight the role of mindset for entrepreneurial success.

\section{CONCLUSIONS}

In this paper, we aimed to examine the complementarity between two types of human capital, namely formal education and professional experience. Building upon two seminal human capital theories, i.e. Lazear's theory of entrepreneurship and Mincer's wage model, we formulated two hypotheses. The first hypothesis stated that education and professional experience are mutually indispensable to succeed as an entrepreneur, whereas the second one that there is a threshold level of both education and professional experience above which they have a positive joint impact. To verify these two hypotheses, we ran a set of logit regressions on the unique sample of data and presented findings. 
Our study confirms the first hypothesis on the existence of complementarity between education and the breadth of professional experience, and the complementarity's impact on the probability of an entrepreneur's success, measured by sustaining a business for at least three consecutive years. Furthermore, we found that the mutual effect between education and professional experience is statistically significant and positive, starting from a threshold value of both human capital proxies. The probability of success increases with the number of fields of studies undertaken (the highest completed level of education), when the number of areas of experience amounts to at least two (when the experience measured with the sum of industries equals to at least two). Moreover, the positive effect of the number of areas of experience (the number of different industries in which the respondents declared professional experience) is triggered by undertaking at least one field of studies. Therefore, our study also confirms the second hypothesis for entrepreneurial success measured by sustaining a business for at least three consecutive years. Our results remain robust to the use of different measures of education and professional experience and toward augmented specifications, which includes proxies for entrepreneurial self-efficacy and being a necessity entrepreneur. Our main conclusion holds - albeit partly - for net income as the measure of entrepreneurial success, i.e. when the number of fields of studies undertaken is used as a proxy for education, along with professional experience measured by the number of areas. The results indicate that the probability of earning the highest income increases with the number of fields of studies undertaken (the number of areas of professional experience) for individuals who possess working experience in at least two different areas (undertaking at least one field of study). At the same time, we revealed the negative impact of education/professional experience on the probability of success measured by income level for entrepreneurs with earnings below 6000 PLN. In light of the presented results, we conclude that there are many shades of entrepreneurial success, and it is important to distinguish between income success and the ultimate measure of entrepreneurial performance: business survival.

Our findings may have practical implications for entrepreneurship research, education, and entrepreneurship practice. The finding on the importance of the measure of entrepreneurial success has a strong value for entrepreneurship research. In any empirical investigations on entrepreneurial success, the choice of measure must be carefully discussed, and the results must be interpreted through the measure's advantages and limits. In order to obtain meaningful findings and a broader picture of a phenomenon, we recommend the application of more than one measure of entrepreneurial success. Our results can also be translated into recommendations for the educational system. Acknowledging the importance of both formal knowledge and professional experience for success as an entrepreneur, we call for curricula to be supplemented with a system of apprenticeships, which will enable future entrepreneurs to acquire sufficient skills before starting their own business. Our results are also advisory for individuals planning or following an entrepreneurial career. They demonstrate that pursuing education and having a breadth of professional experience is a key for business success due to the complementarity between the two. Completing education followed by being active in a business environment - e.g. attending business-related events and workshops, completing business training programs, working in different positions - should help develop stronger entrepreneurial skills and knowledge, which are indispensable for entrepreneurial success. The probability of success increases with professional experience when undertaking at least one field of studies. 
There is no study without limitations; in this case, they are mainly related to the sample used. We tested our hypotheses on individuals from the single-country setting of Poland. When studying one particular context, the generalisation of the findings to other populations starts to be problematic and, therefore, requires additional validation. We know that the specific characteristics of the business framework in Poland might have determined respondents' answers. The measurement of successful entrepreneurship applied in the study may also raise questions. For example, what could shine new light on the problem in question is the employment of a different proxy of entrepreneurial success, namely by extending the survival period to more than three years. Moreover, it may be interesting to confront the self-satisfaction as a subjective measure of entrepreneurial success with the variables used in our study. Potentially, there could also be some shortages in questionnaire. The addition of a few questions to enable answering what particular skills are complementary to each other - and to what extent - could enhance our understanding of the complementarity effect between education and professional experience. Furthermore, it could be informative to track the entrepreneurial path of individuals under study to control for the potential impact of the experience gained while running a business. However, we leave these questions for a follow-up study.

Despite any potential limitations, we hope that the results of this paper have a chance to become a starting point for future investigations on entrepreneurial success, but also for studies aimed at extending Lazear's theory of entrepreneurship.

\section{REFERENCES}

Aldén, L., Hammarstedt, M., \& Neumann, E. (2017). All about balance? A test of the Jack-of-all-Trades theory using military enlistment data. Labour Economics, 49, 1-13.

Åstebro, T., \& Thompson, P. (2011). Entrepreneurs, jacks of all trades or hobos? Research Policy, 40(5), 637-649.

Backes-Gellner, U., \& Moog, P. (2013). The disposition to become an entrepreneur and the jacks-ofall-trades in social and human capital. The Journal of Socio-Economics, 47, 55-72.

Bandura, A. (1995). Self efficacy in changing societies. Cambridge University Press.

Baron, R.A., Mueller, B.A., \& Wolfe, M.T. (2016). Self-efficacy and entrepreneurs' adoption of unattainable goals: The restraining effects of self-control. Journal of Business Venturing, 31(1), 55-71.

Becker, G.S. (1993). Human capital. A theoretical and empirical analysis with special references to education (3rd edition). Chicago: The University of Chicago Press.

Boden Jr, R.J., \& Nucci, A.R. (2000). On the survival prospects of men's and women's new business ventures. Journal of Business Venturing, 15(4), 347-362.

Cope, J. (2005). Toward a dynamic learning perspective of entrepreneurship. Entrepreneurship Theory and Practice, 29(4), 373-397.

Cope, J., \& Watts, G. (2000). Learning by doing - an exploration of experience, critical incidents and reflection in entrepreneurial learning. International Journal of Entrepreneurial Behaviour \& Research, 6(3), 104-124.

Corbett, A.C. (2005). Experiential learning within the process of opportunity identification and exploitation. Entrepreneurship Theory and Practice, 29(4), 473-491. 
CSO. (2014). Creation and operation conditions, development prospects of Polish enterprises established in the years 2008-2012. Retrieved from https://stat.gov.pl/download/gfx/portalinformacyjny/en/defaultaktualnosci/3317/7/3/1/pgwf_creation_and_operation_conditiopns_of_polish_enterprises_2008-2012.pdf on September 15, 2019.

Fairlie, R.W., \& Robb, A.M. (2009). Gender differences in business performance: Evidence from the Characteristics of Business Owners survey. Small Business Economics, 33, 375-395.

Hartog, J., van Praag, M., \& van der Sluis, J. (2010). If you are so smart, why aren't you an entrepreneur? Returns to cognitive and social ability: Entrepreneurs versus employees. Journal of Economics \& Management Strategy, 19(4), 947-989.

Hsieh, C., Parker, S.C., \& van Praag, C.M. (2017). Risk, balanced skills and entrepreneurship. Small Business Economics, 48(2), 287-302.

Iversen, J., Malchow-Møller, N., \& Sørensen, A. (2016). Success in entrepreneurship: a complementarity between schooling and wage-work experience. Small Business Economics, 47, 437-460.

Krueger, N.F., Reilly, M.D., \& Carsrud, A.L. (2000). Competing models of entrepreneurial intentions. Journal of Business Venturing, 15(5-6), 411-432.

Kurczewska, A., Mackiewicz, M., Doryń, W., \& Wawrzyniak, D. (2020). Peculiarity of hybrid entrepreneurs - revisiting Lazear's theory of entrepreneurship. Journal of Business Economics and Management, 21(1), 277-300.

Lamont, M. (2012). Toward a comparative sociology of valuation and evaluation. Annual Review of Sociology, 38(1), 201-221.

Lazear, E.P. (2005). Entrepreneurship. Journal of Labor Economics, 23, 649-680.

Marvel, M.R., Davis, J.L., \& Sproul, C.R. (2016). Human capital and entrepreneurship research: A critical review and future directions. Entrepreneurship Theory and Practice, 40(3), 599-626.

McGee, J.E., Peterson, M., Mueller, S.L., \& Sequeira, J.M. (2009). Entrepreneurial self-efficacy: refining the measure. Entrepreneurship Theory and Practice, 33(4), 965-988.

Mincer, J. (1974). Schooling, experience, and earnings. Human Behavior \& Social Institutions, 2. New York: Columbia University Press.

Nieuwenhuizen, C., Kroon, J. (2002). Identification of entrepreneurial success factors to determine the content of entrepreneurship subjects. South African Journal of Higher Education, 16(3), 157-166.

Orazem, P.F., Jolly, R., \& Yu, L. (2015). Once an entrepreneur, always an entrepreneur? The impacts of skills developed before, during and after college on firm start-ups. IZA Journal of Labor Economics, 4(9), 1-27.

Osborne, R. (1995). The essence of entrepreneurial success. Management Decision, 33(7), 4-9.

Pittaway, L., \& Cope, J. (2007). Simulating entrepreneurial learning integrating experiential and collaborative approaches to learning. Management Learning, 38(2), 211-233.

Politis, D. (2005), The process of entrepreneurial learning: a conceptual framework. Entrepreneurship Theory and Practice, 29(4), 399-424.

Pollack, J.M., Burnette, J.L., \& Hoyt, C.L. (2012). Self-Efficacy in the face of threats to entrepreneurial success: mind-sets matter. Basic and Applied Social Psychology, 34(3), 287-294.

Rae, D., \& Carswell, M. (2001). Towards a conceptual understanding of entrepreneurial learning. Journal of Small Business and Enterprise Development, 8(2), 150-158.

Rasmussen, E.A., \& Sørheim, R. (2006). Action-based entrepreneurship education. Technovation, 26(2), 185-194. 
Saiz-Alvarez, J. (2019). New approaches and theories of entrepreneurship. In M. Corrales-Estrada (Ed.), Innovation and Entrepreneurship: A New Mindset for Emerging Markets (pp. 13-30). Wagon Lane, UK: Emerald Publishing Limited.

Sánchez, J.C. (2011). University training for entrepreneurial competencies: Its impact on intention of venture creation. International Entrepreneurship and Management Journal, 7, 239-254.

Schultz, T.W. (1961). Investment in human capital. American Economic Review, 51(1), 1-17.

Scott, W.R. (2001). Institutions and organizations. London: Sage.

Silva, O. (2007). The jack-of-all-trades entrepreneur: Innate talent or acquired skill? Economics Letters, 97(2), 118-123.

Sorgner, A., \& Fritsch, M. (2018). Entrepreneurial career paths: occupational context and the propensity to become self-employed. Small Business Economics, 51(1), 129-152.

Stuetzer, M., Obschonka, M., Davidsson, P., \& Schmitt-Rodermund, E. (2013). Where do entrepreneurial skills come from?. Applied Economics Letters, 20(12), 1183-1186.

Strohmeyer, R., Tonoyan, V., \& Jennings, J.E. (2017). Jacks-(and Jills)-of-all-trades: On whether, how and why gender influences firm innovativeness. Journal of Business Venturing, 32(5), 498-518.

Tegtmeier, S., \& Kurczewska, A. (2017). Business entry and window of opportunity-empirical results for women entrepreneurs with graduate degree. International Journal of Entrepreneurial Venturing, 9(1), 41-59.

Unger, J.M., Rauch, A., Frese, M., \& Rosenbusch, N. (2011). Human capital and entrepreneurial success: A meta-analytical review. Journal of Business Venturing, 26(3), 341-358.

Wagner, J. (2003). Testing Lazear's jack-of-all-trades view of entrepreneurship with German micro data. Applied Economics Letters, 10(11), 687-689.

Wagner, J. (2006). Are nascent entrepreneurs "Jacks-of-all-trades"? A test of Lazear's theory of entrepreneurship with German data. Applied Economics, 38(20), 2415-2419.

Watson, J. (2003). Failure Rates for Female-Controlled Businesses: Are They Any Different?. Journal of Small Business Management, 41(3), 262-277.

Zhao, H., Seibert, S.E., \& Hills, G.E. (2005). The mediating role of self-efficacy in the development of entrepreneurial intentions. Journal of Applied Psychology, 90, 1265-1272. 


\section{Authors}

The contribution share of authors is equal and amounted to $1 / 3$ for each of them.

\section{Agnieszka Kurczewska}

Associate professor at the Faculty of Economics and Sociology at the University of Lodz, a member of the Board of Directors of the European Council for Small Business and Entrepreneurship (ECSB), associate editor of the Journal of Small Business Management. Her research interests include entrepreneurship and entrepreneurship education.

Correspondence to: Associate Professor Agnieszka Kurczewska, PhD, University of Lodz, Faculty of Economics and Sociology, Institute of Economics, 90-214 Lodz, 41/43 Rewolucji 1905 St. Poland, e-mail: agnieszka.kurczewska@uni.lodz.pl

ORCID (ㄱ) http://orcid.org/0000-0002-3088-5044

\section{Wirginia Doryń}

Assistant Professor in the Department of Economic Mechanisms at the Faculty of Economics and Sociology, the University of Lodz. Master of Economics and Computer Science, PhD in Economics; (University of Lodz, Poland). Her research interests include entrepreneurial success, internationalisation of enterprises, and text data analysis.

Correspondence to: Wirginia Doryń, PhD, University of Lodz, Faculty of Economics and Sociology, Institute of Economics, 90-214 Lodz, 41/43 Rewolucji 1905 St. Poland, e-mail: wirginia.doryn@uni.lodz.pl

ORCID ㄴ http://orcid.org/0000-0001-7112-4295

\section{Dorota Wawrzyniak}

Assistant Professor in the Department of Economic Mechanisms at the Faculty of Economics and Sociology, the University of Lodz. Master of Computer Science and Econometrics, PhD in Economics; (University of Lodz, Poland). Her research interests include entrepreneurial success, foreign direct investment and environmental protection.

Correspondence to: Dorota Wawrzyniak, PhD, University of Lodz, Faculty of Economics and Sociology, Institute of Economics, 90-214 Lodz, 41/43 Rewolucji 1905 St. Poland, e-mail: dorota.wawrzyniak@uni.lodz.pl

ORCID 가 http://orcid.org/0000-0002-2829-3664

\section{Acknowledgements and Financial Disclosure}

The article came into being within the project no. UMO-2016/23/B/HS4/01759 entitled "New approach to Lazear's entrepreneurship theory in context of entrepreneurial success and failure" financed by the National Science Centre in Poland in 2017-2020.

\section{Copyright and License}

This article is published under the terms of the Creative Commons

Attribution - NoDerivs (CC BY-ND 4.0) License

http://creativecommons.org/licenses/by-nd/4.0/

Published by the Centre for Strategic and International Entrepreneurship - Krakow, Poland 
